\title{
ASSESSMENT OF GAMMA DOSE RATE AT MINE WASTE DUMP
}

\author{
OCENA DAWKI PROMIENIOWANIA GAMMA NA ZWAŁOWISKACH
}

\begin{abstract}
Exploitation of coal deposits in Upper Silesia is associated with production of large quantities of waste deposited at dumps. The tested samples from five dumps showed different radioactivity from each other. Radioactivity measurements made it possible to analyze the degree of risk with the factors specified by UNSCEAR such as radium equivalent activity $R a_{e q}$, internal $E_{\text {in }}$ and external $E_{\text {ex }}$ occupancy factor. There is a raised level of radiation in dumps as compared with outside dump areas. In the study area, however, there is no risk associated with elevated levels of radiation in relation to standards established by the Council of Ministers of the ionizing radiation dose limits.
\end{abstract}

Keywords: radiological hazard, radionuclides, radiation dose

\section{Introduction}

One of the key objectives is to assess the radiological protection of human exposure to ionizing radiation, which increased doses significantly affects the health and lives of people. Even small doses of radiation pose a threat to living organisms. It is therefore essential research to assess the radiation dose rate occurring in the environment related to human activities. Such tests allow the limitation of human activity in areas of high radioactivity, as well as allow us to assess whether or exploitation of nuclear power does not adversely affect the environment in connection with the production of waste. Existing in the world, as well as in Poland institutions develop rigorous standards for exposure to radiation, as well as on the use of radioactive materials. All these measures are aimed at one thing, namely the protection of man and his environment against the adverse effects of life radiation.

In the last decade, several studies were carried out to assess the average outdoor terrestrial gamma dose rate in air [1-14].

In this paper the radiological risks associated with the presence of radionuclides in the mine waste dump was assessed. Results of this work are important both in assessment of the risk for human health as well as in development of radiobiomonitoring methods.

\footnotetext{
${ }^{1}$ Independent Chair of Biotechnology and Molecular Biology, Opole University, ul. kard. B. Kominka 6, 45-032 Opole, Poland, phone +48 774016046

*Corresponding author: agna@uni.opole.pl
} 


\section{Materials and methods}

Samples were collected at a coal mine dumps, located in Upper Silesia. Samples were marked according to the scheme $\mathrm{YX}$, where $\mathrm{Y}$ is a dumping ground from which the sample was taken, and $\mathrm{X}$ is the sequence number of sample taken from the dump. Waste dumps from which samples have been taken are:

1. X- KWK "Jankowice"

2. X- KWK "Chwalowice"

3. X- KWK "Marcel"

4. X- KWK "Pniowek"

5. X- KWK "Jankowice"

Sampling were performed on days when there was no chance to rain to avoid the increased concentration of radon that is in the atmosphere and gets along with rainfall in the upper soil layer. Sampling sites were $30 \mathrm{~cm}$ below the top layer of soil, to avoid additional contamination [15]. The structure of the samples was very similar in all sampling points and resembled the finely ground coal, but the weight of each of them were different from each other due to the different content of coal and stone in the sample.

The geographical coordinates and the weight to be sampled

Table 1

\begin{tabular}{|c|c|c|c|}
\hline Sample number & Latitude & Longitude & Sample weight \\
\hline 1.1 & $50^{\circ} 01^{\prime} 58.90^{\prime \prime} \mathrm{N}$ & $18^{\circ} 33^{\prime} 00.35^{\prime \prime} \mathrm{E}$ & $362.2 \mathrm{~g}$ \\
\hline 1.2 & $50^{\circ} 01^{\prime} 58.56^{\prime \prime} \mathrm{N}$ & $18^{\circ} 32^{\prime} 55.33^{\prime \prime} \mathrm{E}$ & $464.3 \mathrm{~g}$ \\
\hline 1.3 & $50^{\circ} 01^{\prime} 55.35^{\prime \prime} \mathrm{N}$ & $18^{\circ} 32^{\prime} 56.12^{\prime \prime} \mathrm{E}$ & $556.8 \mathrm{~g}$ \\
\hline 1.4 & $50^{\circ} 01^{\prime} 55.87^{\prime \prime} \mathrm{N}$ & $18^{\circ} 33^{\prime} 01.01^{\prime \prime} \mathrm{E}$ & $653.2 \mathrm{~g}$ \\
\hline 1.5 & $50^{\circ} 01^{\prime} 57.17^{\prime \prime} \mathrm{N}$ & $18^{\circ} 32^{\prime} 58.31^{\prime \prime} \mathrm{E}$ & $649.8 \mathrm{~g}$ \\
\hline 2.1 & $50^{\circ} 03^{\prime} 36.07^{\prime \prime} \mathrm{N}$ & $18^{\circ} 32^{\prime} 18.57^{\prime \prime} \mathrm{E}$ & $660.5 \mathrm{~g}$ \\
\hline 2.2 & $50^{\circ} 03^{\prime} 36.11^{\prime \prime} \mathrm{N}$ & $18^{\circ} 32^{\prime} 23.61^{\prime \prime} \mathrm{E}$ & $593.1 \mathrm{~g}$ \\
\hline 2.3 & $50^{\circ} 03^{\prime} 39.35^{\prime \prime} \mathrm{N}$ & $18^{\circ} 32^{\prime} 23.46^{\prime \prime} \mathrm{E}$ & $609.1 \mathrm{~g}$ \\
\hline 2.4 & $50^{\circ} 03^{\prime} 39.33^{\prime \prime} \mathrm{N}$ & $18^{\circ} 32^{\prime} 18.69^{\prime \prime} \mathrm{E}$ & $654.1 \mathrm{~g}$ \\
\hline 2.5 & $50^{\circ} 03^{\prime} 37.75^{\prime \prime} \mathrm{N}$ & $18^{\circ} 32^{\prime} 21.12^{\prime \prime} \mathrm{E}$ & $688.1 \mathrm{~g}$ \\
\hline 3.1 & $50^{\circ} 02^{\prime} 23.33^{\prime \prime} \mathrm{N}$ & $18^{\circ} 28^{\prime} 43.22^{\prime \prime} \mathrm{E}$ & $638.7 \mathrm{~g}$ \\
\hline 3.2 & $50^{\circ} 02^{\prime} 23.23^{\prime \prime} \mathrm{N}$ & $18^{\circ} 28^{\prime} 38.16^{\prime \prime} \mathrm{E}$ & $583.5 \mathrm{~g}$ \\
\hline 3.3 & $50^{\circ} 02^{\prime} 26.39^{\prime \prime} \mathrm{N}$ & $18^{\circ} 28^{\prime} 37.03^{\prime \prime} \mathrm{E}$ & $611.7 \mathrm{~g}$ \\
\hline 3.4 & $50^{\circ} 02^{\prime} 26.58^{\prime \prime} \mathrm{N}$ & $18^{\circ} 28^{\prime} 42.05^{\prime \prime} \mathrm{E}$ & $719.8 \mathrm{~g}$ \\
\hline 3.5 & $50^{\circ} 02^{\prime} 24.86^{\prime \prime} \mathrm{N}$ & $18^{\circ} 28^{\prime} 40.15^{\prime \prime} \mathrm{E}$ & $649.9 \mathrm{~g}$ \\
\hline 4.1 & $49^{\circ} 58^{\prime} 48.56^{\prime \prime} \mathrm{N}$ & $18^{\circ} 39^{\prime} 52.12^{\prime \prime} \mathrm{E}$ & $565.1 \mathrm{~g}$ \\
\hline 4.2 & $49^{\circ} 58^{\prime} 48.43^{\prime \prime} \mathrm{N}$ & $18^{\circ} 39^{\prime} 47.06^{\prime \prime} \mathrm{E}$ & $381.3 \mathrm{~g}$ \\
\hline 4.3 & $49^{\circ} 58^{\prime} 45.25^{\prime \prime} \mathrm{N}$ & $18^{\circ} 39^{\prime} 47.94^{\prime \prime} \mathrm{E}$ & $433.6 \mathrm{~g}$ \\
\hline 4.4 & $49^{\circ} 58^{\prime} 45.42^{\prime \prime} \mathrm{N}$ & $18^{\circ} 39^{\prime} 53.01^{\prime \prime} \mathrm{E}$ & $639.0 \mathrm{~g}$ \\
\hline 4.5 & $49^{\circ} 58^{\prime} 46,90^{\prime \prime} \mathrm{N}$ & $18^{\circ} 39^{\prime} 50.12^{\prime \prime} \mathrm{E}$ & $697.2 \mathrm{~g}$ \\
\hline 5.1 & $50^{\circ} 03^{\prime} 37.00^{\prime \prime} \mathrm{N}$ & $18^{\circ} 34^{\prime} 40.90^{\prime \prime} \mathrm{E}$ & $532.8 \mathrm{~g}$ \\
\hline 5.2 & $50^{\circ} 03^{\prime} 37.84^{\prime \prime} \mathrm{N}$ & $18^{\circ} 34^{\prime} 45.75^{\prime \prime} \mathrm{E}$ & $526.1 \mathrm{~g}$ \\
\hline 5.3 & $50^{\circ} 03^{\prime} 40.98^{\prime \prime} \mathrm{N}$ & $18^{\circ} 34^{\prime} 44.59^{\prime \prime} \mathrm{E}$ & $698.0 \mathrm{~g}$ \\
\hline 5.4 & $50^{\circ} 03^{\prime} 40.20^{\prime \prime} \mathrm{N}$ & $18^{\circ} 34^{\prime} 39.71^{\prime \prime} \mathrm{E}$ & $582.2 \mathrm{~g}$ \\
\hline 5.5 & $50^{\circ} 03^{\prime} 39.00^{\prime \prime} \mathrm{N}$ & $18^{\circ} 34^{\prime} 42.77^{\prime \prime} \mathrm{E}$ & $708.7 \mathrm{~g}$ \\
\hline
\end{tabular}

To test the activity of radionuclides in the samples taken were used semiconductor gamma spectrometer with Canberra's high resolution germanium coaxial detector (HPGe). Resolution for $1.33 \mathrm{MeV}$ line is $1.70 \mathrm{keV}$ and $0.662 \mathrm{MeV}$ line is $1.29 \mathrm{keV}$. Calibration was 
made using Marinelli container with a volume of $447.7 \pm 4.48 \mathrm{~cm}^{3}$. The density of the source to the calibration was $0.985 \pm 0.01 \mathrm{~g} / \mathrm{cm}^{3}$, and it contained a mixture of radioactive radionuclides, such as ${ }^{241} \mathrm{Am},{ }^{109} \mathrm{Cd},{ }^{139} \mathrm{C},{ }^{57} \mathrm{Co},{ }^{60} \mathrm{Co},{ }^{137} \mathrm{Cs},{ }^{113} \mathrm{Sn},{ }^{85} \mathrm{Sr},{ }^{88} \mathrm{Y},{ }^{203} \mathrm{Hg}$. Source used for calibration were from the Czech Institute of Metrology in Prague. The volume of collected and tested samples were comparable to the source calibration, which is not required to make amendments in the calculation of specific activity. Spectrum analysis was performed using the GENIE-2000 software (Gamma Analysis Option model S501C). Before the measurement samples were dried, weighed and then placed in a Marinelli containers for 4 weeks to the radioactive equilibrium and avoid signs of ${ }^{222} \mathrm{Rn},{ }^{220} \mathrm{Rn}$ and their short life fission products, which could affect the measurement result [16]. The mean volume of samples was $450 \mathrm{~cm}^{3}$.

\section{Results and discussions}

The results of the activity of individual samples analyzed using the gamma spectrometer were characterized by different levels of measurement uncertainty. In order to obtain the most reliable results was calculated rate measurement uncertainty for each nuclide, and then to carry out the calculations were selected nuclides with the smallest uncertainty of measurement. Table 2 shows the average percentage uncertainty of measurement of activity for specified nuclides.

Table 2

Average percentage of the uncertainty of measurement for specified nuclides activity

\begin{tabular}{|c|c|}
\hline $\begin{array}{c}\text { Nuclide } \\
\text { name }\end{array}$ & $\begin{array}{c}\text { Average uncertainty } \\
{[\%]}\end{array}$ \\
\hline${ }^{40} \mathrm{~K}$ & 4.2 \\
\hline${ }^{208} \mathrm{Tl}$ & 61 \\
\hline${ }^{212} \mathrm{Bi}$ & 12 \\
\hline${ }^{212} \mathrm{~Pb}$ & 3.7 \\
\hline${ }^{214} \mathrm{Bi}$ & 3.3 \\
\hline${ }^{214} \mathrm{~Pb}$ & 4.1 \\
\hline${ }^{228} \mathrm{Ac}$ & 2.7 \\
\hline
\end{tabular}

Assuming that each of the radioactive series is in equilibrium, a sufficient knowledge of the activity is only one element of a series such as ${ }^{214} \mathrm{Bi}$ for a number of ${ }^{238} \mathrm{U}$ and ${ }^{232} \mathrm{Th}$, ${ }^{228} \mathrm{Ac}$ for a range of [17]. The analysis of measurement uncertainty Table is selected to analyze the results of activity of individual isotopes:

- ${ }^{40} \mathrm{~K}$ with an average measurement uncertainty of $4.2 \%$,

- $\quad{ }^{214} \mathrm{Bi}$ to ${ }^{238} \mathrm{U}$ series with an average uncertainty of $3.3 \%$,

- $\quad{ }^{228} \mathrm{Ac}$ to ${ }^{232} \mathrm{Th}$ series with an average uncertainty of $2.7 \%$.

The results of a series of activity measurements of isotopes ${ }^{238} \mathrm{U},{ }^{232} \mathrm{Th}$ and ${ }^{40} \mathrm{~K}$ are shown in Table 3.

Analyzing these results, activity measurements can be stated that they are close to each other in the area of individual waste dumps, but between other waste dumps are already much bigger differences. ${ }^{40} \mathrm{~K}$ activity peaked in the sample 2.1 , amounting to $810 \mathrm{~Bq} / \mathrm{kg}$ and the minimum in a sample of $4.2-378 \mathrm{~Bq} / \mathrm{kg}$. ${ }^{214} \mathrm{Bi}$ activity for a number of ${ }^{238} \mathrm{U}$ in the sample has reached the maximum value of 2.4 to $59.7 \mathrm{~Bq} / \mathrm{kg}$ and the minimum value of 
$36.04 \mathrm{~Bq} / \mathrm{kg}$ in a sample of 4.2. The values of maximum activity and minimum for ${ }^{228} \mathrm{Ac}$ which represents the number of radionuclides ${ }^{232} \mathrm{Th}$ are respectively $72.3 \mathrm{~Bq} / \mathrm{kg}$ for a sample of 3.2 and $45.2 \mathrm{~Bq} / \mathrm{kg}$ for sample 1.4 .

Table 3

The results of activity measurements of test samples

\begin{tabular}{|c|c|c|c|}
\hline $\begin{array}{l}\text { Sample } \\
\text { number }\end{array}$ & $\begin{array}{c}\text { Activity } \\
{ }^{40} \mathrm{~K}[\mathrm{~Bq} / \mathrm{kg}]\end{array}$ & $\begin{array}{c}\text { Activity } \\
{ }^{238} \mathrm{U}[\mathrm{Bq} / \mathrm{kg}]\end{array}$ & $\begin{array}{c}\text { Activity }{ }^{232} \mathrm{Th} \\
{[\mathrm{Bq} / \mathrm{kg}]}\end{array}$ \\
\hline 1.1 & 423 & 46.2 & 48.0 \\
\hline 1.2 & 435 & 38.2 & 46.3 \\
\hline 1.3 & 433 & 40.5 & 48.5 \\
\hline 1.4 & 483 & 41.1 & 45.2 \\
\hline 1.5 & 693 & 53.8 & 63.5 \\
\hline Average & 493 & 44.0 & 50.3 \\
\hline 2.1 & 810 & 52.9 & 64.1 \\
\hline 2.2 & 729 & 52.8 & 62.9 \\
\hline 2.3 & 781 & 54.1 & 65.1 \\
\hline 2.4 & 805 & 59.7 & 69.0 \\
\hline 2.5 & 747 & 54.8 & 66.3 \\
\hline Average & 774 & 54.9 & 65.5 \\
\hline 3.1 & 680 & 51.2 & 69.1 \\
\hline 3.2 & 766 & 58.4 & 75.3 \\
\hline 3.3 & 698 & 47.8 & 63.3 \\
\hline 3.4 & 725 & 56.4 & 71.4 \\
\hline 3.5 & 739 & 56.6 & 64.7 \\
\hline Average & 722 & 54.1 & 68.8 \\
\hline 4.1 & 688 & 57.3 & 68.0 \\
\hline 4.2 & 378 & 36.0 & 46.1 \\
\hline 4.3 & 595 & 54.6 & 59.1 \\
\hline 4.4 & 719 & 55.9 & 70.2 \\
\hline 4.5 & 710 & 55.6 & 64.0 \\
\hline Average & 618 & 51.9 & 61.5 \\
\hline 5.1 & 516 & 46.4 & 51.7 \\
\hline 5.2 & 605 & 51.1 & 57.9 \\
\hline 5.3 & 779 & 53.1 & 70.9 \\
\hline 5.4 & 692 & 45.6 & 64.4 \\
\hline 5.5 & 728 & 54.8 & 66.6 \\
\hline Average & 664 & 50.2 & 62.3 \\
\hline
\end{tabular}

Comparing the measured activity to the average activity in the world, which are respectively $33 \mathrm{~Bq} / \mathrm{kg}$ for ${ }^{238} \mathrm{U}, 45 \mathrm{~Bq} / \mathrm{kg}$ for ${ }^{232} \mathrm{Th}$ and $412 \mathrm{~Bq} / \mathrm{kg}$ for ${ }^{40} \mathrm{~K}$ [18], we obtain the results exceeded the activity for all tested samples for the ${ }^{238} \mathrm{U}$ and ${ }^{232} \mathrm{Th}$. However, in the case of ${ }^{40} \mathrm{~K}$, only the activity of one sample does not exceed the average value of activity in the world. Comparing the measured activity to the average value of activity in Poland, the results presented in the same way as for the mean activity in the world, but if we take into account the range of measured values of activity in Poland, the situation changes dramatically. The range of values of the measured activity in Poland is, respectively: $110-970 \mathrm{~Bq} / \mathrm{kg}$ for ${ }^{40} \mathrm{~K}, 5-120 \mathrm{~Bq} / \mathrm{kg}$ for ${ }^{238} \mathrm{U}$, and $4-77 \mathrm{~Bq} / \mathrm{kg}$ for ${ }^{232} \mathrm{Th}$ [19]. By analyzing the ranges and the measured activity, we see that the activity of all measured isotopes falls within the ranges recorded in Poland. Only in the case of ${ }^{232} \mathrm{Th}$ the maximum activity 
measured activity reaches the maximum value given by UNSCEAR. In other cases, the measured values are well below the maximum recorded on Polish territory.

The results of activity measurements of radionuclides in the samples were used to calculate:

- $R a_{e q}$ - radium equivalent activity $[\mathrm{Bq} / \mathrm{kg}]$

- D - from the air absorbed dose of gamma radiation $[\mathrm{nGy} / \mathrm{h}]$;

- $E_{e x}$ - annual external effective dose [mSv/year];

- $E_{\text {in }} \quad$ - annual internal effective dose [mSv/year].

The distribution of radioactive series decay products of ${ }^{238} \mathrm{U},{ }^{232} \mathrm{Th}$ and ${ }^{40} \mathrm{~K}$ in the environment is not homogeneous, and to harmonize terms of radiation exposure, radioactivity was expressed as the equivalent of radium $R a_{e q}$ activity expressed in $\mathrm{Bq} / \mathrm{kg}$. Radium equivalent activity was introduced in order to compare the specific activity of materials containing different values of the activity of ${ }^{238} \mathrm{U},{ }^{232} \mathrm{Th}$ and ${ }^{40} \mathrm{~K}$ [20]. The equation is based on a factor which was identified on the activity of individual rows. $10 \mathrm{~Bq} / \mathrm{kg}$ of ${ }^{238} \mathrm{U}$ to $7 \mathrm{~Bq} / \mathrm{kg}$ of ${ }^{232} \mathrm{Th}$ and $130 \mathrm{~Bq} / \mathrm{kg}{ }^{40} \mathrm{~K}$. Mathematically, is defined as follows [19]

$$
R a_{\text {eq }}=\left(A_{K} \cdot R_{K}\right)+\left(A_{U} \cdot R_{U}\right)+\left(A_{T h} \cdot R_{T h}\right)
$$

where: $R a_{e q}$ - radium equivalent activity [Bq/kg], $A_{K}-{ }^{40} \mathrm{~K}$ specific activity $[\mathrm{Bq} / \mathrm{kg}]$, $A_{U}$ - a series of uranium specific activity $[\mathrm{Bq} / \mathrm{kg}], A_{T h}$ - a series of thorium specific activity $[\mathrm{Bq} / \mathrm{kg}], R_{K}=0.077$ - a conversion rate of activity for the ${ }^{40} \mathrm{~K}, R_{U}=1$ - a conversion factor for a number of uranium activity, $R_{T h}=1.43$ - a conversion factor for a number of thorium activity rate.

Gamma radiation dose absorbed from the air is calculated for gamma rays originating from the substrate at a height of 1 meter and is expressed in $\mathrm{nGy} / \mathrm{h}$ or $\mathrm{pGy} / \mathrm{h}$. The conversion factors are determined for the average concentration of radionuclides from each radioactive series [21]. We calculate it using the formula [19]

$$
D=\left(R_{K} \cdot A_{K}\right)+\left(R_{U} \cdot A_{U}\right)+\left(R_{T h} \cdot A_{T h}\right)
$$

where: $D$ - from the air absorbed dose of gamma radiation $[\mathrm{nGy} / \mathrm{h}], R_{K}$ - a conversion rate of 0.043 for ${ }^{40} \mathrm{~K}, R_{U}$ - conversion factor for a number of uranium amounting to 0.427 , $R_{T h}$ - conversion factor for a number of thorium rate of $0.662, A_{K}-{ }^{40} \mathrm{~K}$ specific activity $[\mathrm{Bq} / \mathrm{kg}], A_{U}-$ a series of uranium specific activity $[\mathrm{Bq} / \mathrm{kg}], A_{T h}-$ a series of thorium specific activity $[\mathrm{Bq} / \mathrm{kg}]$.

For the determination of annual effective dose should be taken into account the conversion factor from absorbed dose in air $(D)$ and the internal rate of occupancy. Mean values of these parameters depend on the age of the population and the location of the climatic conditions taken into consideration. The UNSCEAR report of 1993, commission used the conversion factor for absorbed dose in air at $0.7 \mathrm{~Sv} / \mathrm{Gy}$ and factors internal and external cladding of respectively 0.2 and 0.8 . These factors have been also used in this work. These coefficients were adopted for the average time that people spend outdoors [22]. The effective annual dose of radiation is expressed in nSv/year. For the calculations we use the following formulas established by UNSCEAR [23]

$$
E=D \cdot A_{t} \cdot O f \cdot R_{D}
$$


where: $E$ - the annual effective dose of radiation [nSv/year], $D$ - from the air absorbed dose of gamma radiation $[\mathrm{nGy} / \mathrm{h}], A_{t}$ - the number of hours per year [h], Of - occupancy rate, $O f_{e x}-0.8 ; O f_{i n}-0.2, R_{D}$ - absorbed dose conversion factor in air of $0.7 \mathrm{~Sv} / \mathrm{Gy}$.

For the purpose of operating result was multiplied by $10^{-3}$ to get the results in $\mathrm{mSv} /$ year. Calculated values $R a_{e q}, D, E_{i n}, E_{e x}$ are presented in Table 4.

Table 4

Calculated values $R a_{e q}, D, E_{\text {in }}, E_{e x}$

\begin{tabular}{|c|c|c|c|c|}
\hline $\begin{array}{l}\text { Sample } \\
\text { number }\end{array}$ & $\begin{array}{c}\text { Absorbed dose of } \\
\text { gamma radiation } D \\
{[\mathrm{nGy} / \mathrm{h}]}\end{array}$ & $\begin{array}{c}\text { Annual effective dose } \\
\text { of radiation } \\
E_{e x}[\mu \mathrm{Sv} / \text { year }] \\
\end{array}$ & $\begin{array}{c}\text { Annual effective dose of } \\
\text { radiation } \\
E_{\text {in }}[\mu \mathrm{Sv} / \mathrm{year}] \\
\end{array}$ & $\begin{array}{c}\text { Radium equivalent } \\
\text { activity } \\
R a_{e q}[\mathrm{~Bq} / \mathrm{kg}] \\
\end{array}$ \\
\hline 1.1 & 70 & 85 & 342 & 147 \\
\hline 1.2 & 66 & 80 & 322 & 138 \\
\hline 1.3 & 68 & 83 & 334 & 143 \\
\hline 1.4 & 68 & 84 & 335 & 143 \\
\hline 1.5 & 95 & 116 & 465 & 198 \\
\hline Average & 73 & 90 & 359 & 154 \\
\hline 2.1 & 100 & 122 & 490 & 207 \\
\hline 2.2 & 96 & 117 & 469 & 199 \\
\hline 2.3 & 100 & 122 & 489 & 207 \\
\hline 2.4 & 106 & 130 & 519 & 220 \\
\hline 2.5 & 99 & 122 & 488 & 207 \\
\hline Average & 100 & 123 & 491 & 208 \\
\hline 3.1 & 97 & 119 & 475 & 202 \\
\hline 3.2 & 108 & 132 & 529 & 225 \\
\hline 3.3 & 92 & 113 & 453 & 192 \\
\hline 3.4 & 103 & 126 & 503 & 214 \\
\hline 3.5 & 99 & 121 & 485 & 206 \\
\hline Average & 100 & 122 & 489 & 208 \\
\hline 4.1 & 99 & 121 & 486 & 208 \\
\hline 4.2 & 62 & 76 & 305 & 131 \\
\hline 4.3 & 88 & 108 & 432 & 185 \\
\hline 4.4 & 101 & 124 & 497 & 212 \\
\hline 4.5 & 97 & 119 & 474 & 208 \\
\hline Average & 89 & 110 & 439 & 187 \\
\hline 5.1 & 76 & 94 & 374 & 160 \\
\hline 5.2 & 86 & 106 & 423 & 180 \\
\hline 5.3 & 103 & 126 & 506 & 214 \\
\hline 5.4 & 92 & 113 & 451 & 191 \\
\hline 5.5 & 99 & 121 & 485 & 206 \\
\hline Average & 91 & 119 & 447 & 190 \\
\hline
\end{tabular}

Calculated values $R a_{e q}, D, E_{i n}, E_{e x}$ was compared with the data presented in PAA report of 2011 year [24] and UNSCEAR 2000 [20]. Data in PAA report of 2011 year refer to the values measured on Polish territory with PMS station and IMiGW. The data presented in the UNSCEAR 2000 report on selected countries of the world and show average values and ranges of measured doses of radiation. Absorbed radiation dose $D$ calculated from the specific activities identified nuclides in the range $62-108 \mathrm{nGy} / \mathrm{h}$, with a mean value of $97 \mathrm{nGy} / \mathrm{h}$ from the data presented in the report with 2011 years PAA measured gamma radiation dose rate ranged from 60 to $179 \mathrm{nGy} / \mathrm{h}$, with an average of $95 \mathrm{nGy} / \mathrm{h}$. The results indicate that the dose of gamma radiation on the investigated area is in the range of doses 
measured on Polish territory in 2011. According to the UNSCEAR 2000 report, the average annual value of the radiation absorbed dose rate in the world amounts to $57 \mathrm{nGy} / \mathrm{h}$. Comparison of the calculated dose of radiation with an average dose of radiation in Poland and the world is shown in Figure 1.

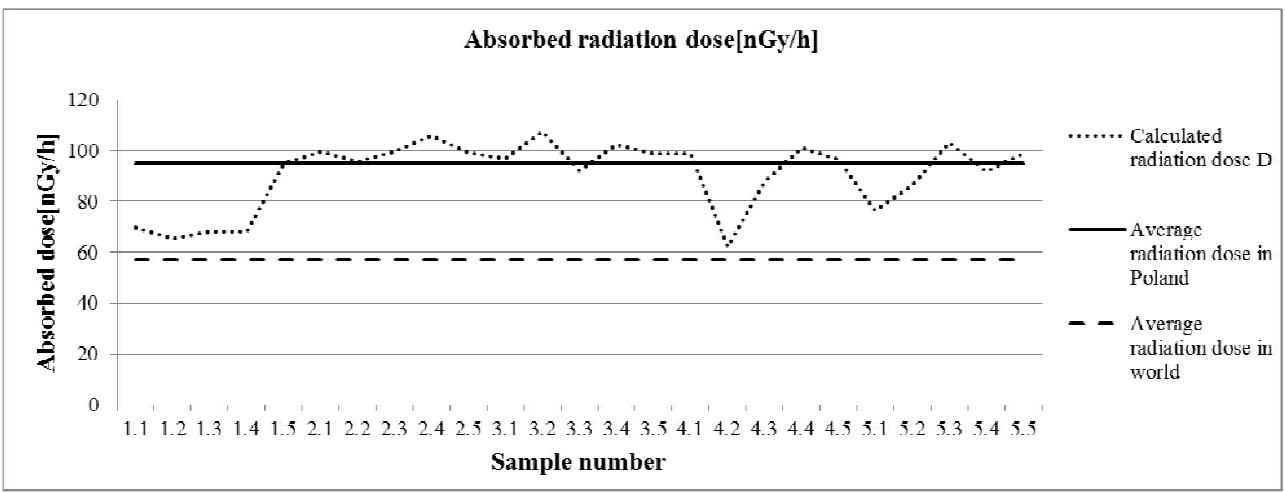

Fig. 1. Comparison of the calculated dose of radiation with an average dose of radiation in Poland and abroad

By analyzing Figure 1, we can conclude that the results significantly exceed the average dose measured in the world, even the lowest calculated value is above the world average. The range of doses of gamma radiation in the world is $18-93 \mathrm{nGy} / \mathrm{h}$, the results obtained in the case of 15 samples are outside this range.

Calculated values of gamma radiation absorbed dose $D$ were used to calculate the annual effective dose equivalent. In this work two equivalents were calculated annual effective dose equivalent, and equivalent to the external and internal $E_{e x}, E_{i n}$, differing by a factor of occupancy (Fig. 2).

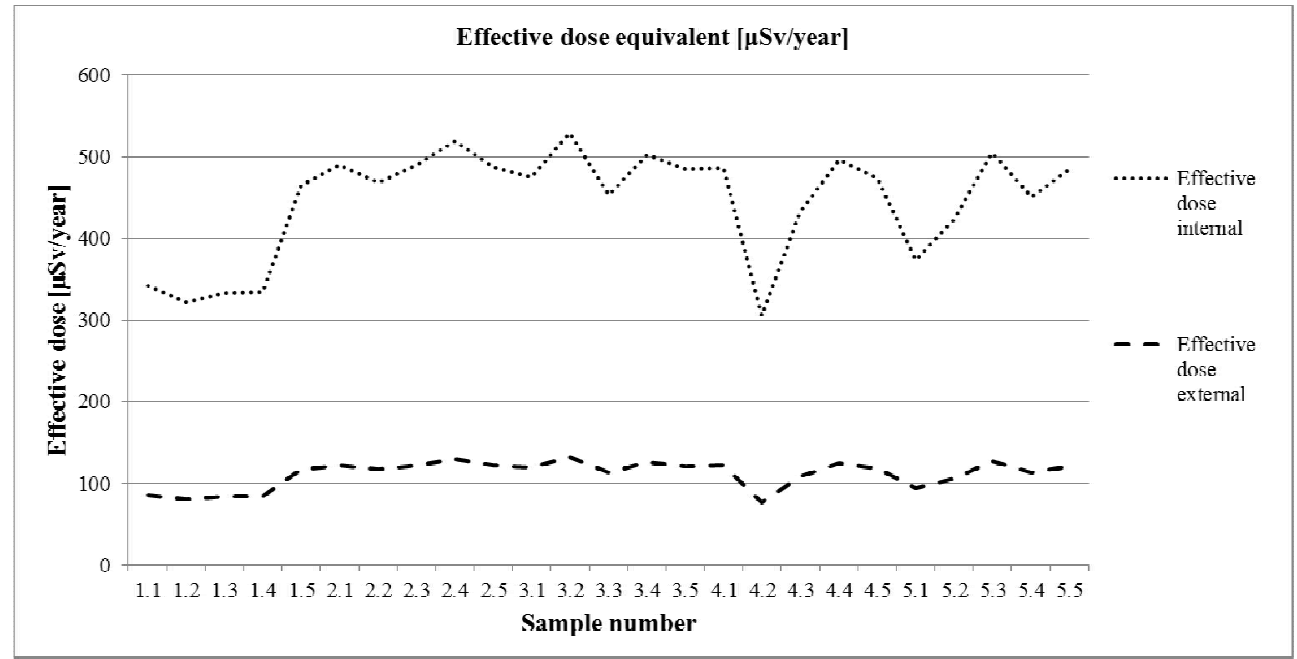

Fig. 2. Effective dose equivalent to $E_{i n}, E_{e x}$ 
The value range of the $E_{\text {in }}$ is $305-529 \mathrm{mSv} / \mathrm{year}$, with an average of $474 \mathrm{mSv} / \mathrm{year}$. The value range of it is $E_{e x} 76-132 \mathrm{mSv} / \mathrm{year}$, with an average of $119 \mathrm{mSv} / \mathrm{year}$. $E_{e x}$ values are above the average annual effective dose equivalent of the equivalent of $70 \mathrm{mSv} / \mathrm{year}$ for the equivalent of an external set by UNSCEAR [19]. However, the measured values are below the limits set by UNSCEAR, amounting to $1.5 \mathrm{mSv} /$ year for natural radioactive sources. In Poland, the legal act regulating the radiation dose limit is the Council of Ministers of 18 January 2005 on ionizing radiation dose limits (Journal of Laws of 2005 No. 20, item 168). This document states that for the general public dose limit (caused primarily by artificial sources of ionizing radiation), expressed as effective dose is $1 \mathrm{mSv}$ per calendar year. This dose may be in a calendar year exceeded, provided that in the next five calendar years, the total value does not exceed $5 \mathrm{mSv}$ [25]. PAA according to the report for 2011 year "it is estimated that the annual effective dose of ionizing radiation received by a statistical Polish citizen from natural and artificial sources of ionizing radiation in 2011 was an average of $3.3 \mathrm{mSv}$, ie, remained at the level the past few years" [24]. Thus, the calculated values of gamma radiation in samples defining the equivalent annual effective dose equivalent is, in the case of $E_{i n} 52 \%$ of the annual dose limit, and for $E_{e x} 13 \%$ of the annual dose limit.

Figure 3 shows the calculated values of radium equivalent activity for individual sites.

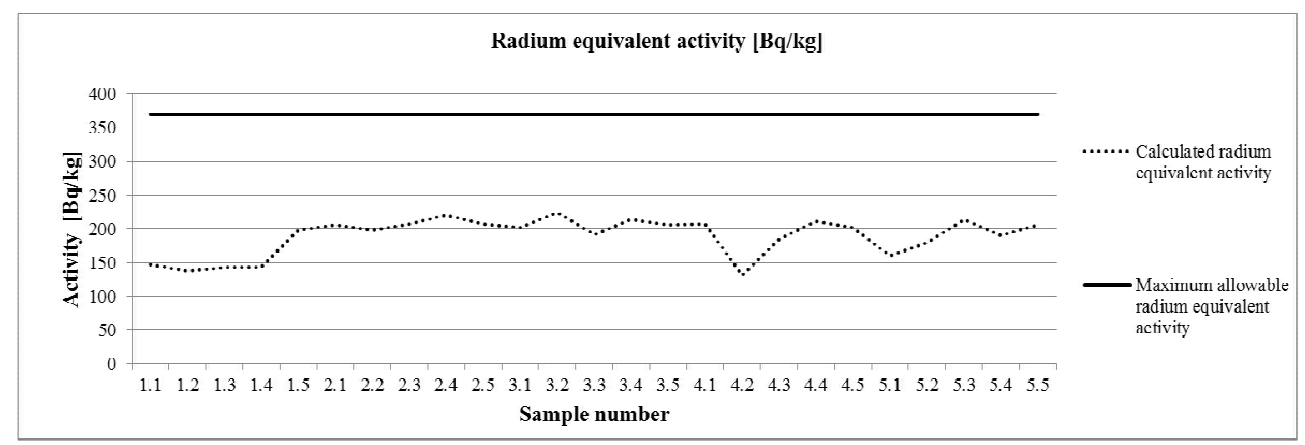

Fig. 3. $R a_{e q}$ radium equivalent activity for individual sites

Radium equivalent activity calculated on the basis of specific activity was located in the $131-225 \mathrm{~Bq} / \mathrm{kg}$, and its average value was $202 \mathrm{~Bq} / \mathrm{kg}$. UNSCEAR determined by the maximum radium equivalent activity $R a_{e q}$ is $370 \mathrm{~Bq} / \mathrm{kg}$ which corresponds to $1.5 \mathrm{mSv} /$ year, which is the maximum permissible dose for humans from natural radioactive sources during the year. The samples analyzed in each case was equivalent to less than the maximum value, which corresponds to the calculations carried out to determine the annual dose equivalent to $E_{e x}$.

\section{Conclusions}

The conducted research in Silesia, which concerned only 5 dumps, allow to stated that there is not the very dangerous levels of radiation. All activity of the samples included in the average values for the area of our country, according to a report by UNSCEAR 2000. Radiation absorbed dose values were within the average values for the Polish territory, and 
the internal and external annual equivalent dose equivalent does not exceed the limit values laid down by the ruling of the Council of Ministers of 18 January 2005 on the dose limits of ionizing radiation (Journal of Laws of 2005 No. 20, item 168). In addition, marked radium equivalent activity, as determined by UNSCEAR at $370 \mathrm{~Bq} / \mathrm{kg}$ also was below this value. The calculated value of the absorbed dose in relation to the average values in the world amounting to $57 \mathrm{nGy} / \mathrm{h}$ is much higher, but it is related to geological considerations of Polish territory, where the annual effective dose from natural sources of radiation is $2.43 \mathrm{mSv} /$ year.

Based on the obtained results it can be concluded that ionizing radiation present in the studied dump does not exceed acceptable standards and, therefore, operated by mines, dump the research subject, the deposit does not contain a higher concentration of radionuclides. Thus, the use of materials on dumps as construction aggregates will have no negative effect at the point of use. Reclamation of dumps also carries no risk to animals and plants inhabiting new areas. In addition, it can be stated that the mines which tip waste dumps on the test there is not an increased risk to ionizing radiation. According to the report for 2011 PAA risk is only in 14 mines in our country.

Another important conclusion drawn from this study, given the practical aspects, it is possible to determine the radiation dose on the basis of activity of the radionuclide in the laboratory using the theoretical conversion rates. Such tests are preferred because of the ability to compare the results of a variety of different areas of the world, on the basis of the measured activity, and their conversion to various specific factors or equivalents. Such calculations have been confirmed in a number of research work carried out around the world and characterized by low coefficients of error for the research conducted in the field. As mentioned at the beginning of this work ionizing radiation is all around us and accompanies us every day but when examined dumps, it is at a safe level, which does not adversely affect living in the vicinity in radiological terms.

\section{References}

[1] Al-Hamarneh IF, Awadallah MI. Soil radioactivity levels and radiation hazard assessment in the highlands of northern Jordan. Radiat Measurm. 2009;44:102-110. DOI: 10.1016/j.radmeas.2008.11.005.

[2] Baykara O, Doğru M. Determination of terrestrial gamma, ${ }^{238} \mathrm{U},{ }^{232} \mathrm{Th}$ and ${ }^{40} \mathrm{~K}$ in soil along fracture zones. Radiat Measurm. 2009;44:116-121. DOI:10.1016/j.radmeas.2008.10.001.

[3] Belivermis M, Kılıç Ö, Çotuk Y, Topcuoğlu S. The effects of physicochemical properties on gamma emitting natural radionuclide levels in the soil profile of Istanbul. Environ. Monit. Assess. 2010;163:15-26. DOI: 10.1007/s10661-009-0812-1.

[4] Degerlier M, Karahan G, Ozger G. Radioactivity concentrations and dose assessment for soil samples around Adana, Turkey. J Environ Radioact. 2008;99:1018-1025. DOI:10.1016/j.jenvrad.2007.12.015.

[5] Dołhańczuk-Śródka A. Estimation of external gamma radiation dose in the area of Bory Stobrawskie forests (PL). Environ Monit Assess. 2012;184:5773-5779. DOI 10.1007/s10661-011-2380-4.

[6] El-Taher A, Makhluf S, Nossair A, Abdel Halim AS. Assessment of natural radioactivity levels and radiation hazards due to cement industry. Appl Radiat Isotopes. 2010;68:169-174. DOI: 10.1016/j.apradiso.2009.09.001.

[7] Faheem M, Mujahid SA, Matiullah M. Assessment of radiological hazards due to the natural radioactivity in soil and building material samples collected from six districts of the Punjab province-Pakistan. Radiat Meas. 2008;43:1443-1447. DOI: 10.1016/j.radmeas.2008.02.014.

[8] Janković M, Todorović D, Savanović M. Radioactivity measurements in soil samples collected in the Republic of Srpska. Radiat Meas. 2008;43:1448-1452. DOI: 10.1016/j.radmeas.2008.03.004. 
[9] Lee SK, Wagiran H, Ramli AT, Apriantoro NH, Wood AK. Radiological monitoring: terrestrial natural radionuclides in Kinta District, Perak, Malaysia. J Environ Radioact. 2009;100:368-374. DOI: 10.1016/j.jenvrad.2009.01.001.

[10] Nada A, Abd-El Maksoud TM, Abu-Zeid Hosnia M, El-Nagar T, Awad S. Distribution of radionuclides in soil samples from a petrified wood forest in El-Qattamia, Cairo, Egypt. Appl Radiat Isotopes. 2009;67:643-649. DOI: 10.1016/j.apradiso.2008.11.016.

[11] Ngachin M, Garavaglia M, Giovani C, Kwato Njock MG, Nourreddine A. Radioactivity level and soil radon measurement of a volcanic area in Cameroon. J Environ Radioact. 2008;99:1056-1060. DOI: 10.1016/j.jenvrad.2007.12.022.

[12] Psichoudaki M, Papaefthymiou H. Natural radioactivity measurements in the city of Ptolemais (Northern Greece). J Environ Radioact. 2008;99:1011-1017. DOI: 10.1016/j.jenvrad.2007.12.001.

[13] Radenković M, Alshikh SM, Andrić VB, Miljanić ŠS. Radioactivity of sand from several renowned public beaches and assessment of the corresponding environmental risks. J Serb Chem Soc. 2009;74(4):461-470. DOI: 10.2298/JSC0904461R.

[14] Taskin H, Karavus M, Ayb P, Topuzoglu A, Hidiroglu S, Karahan G. Radionuclide concentrations in soil and lifetime cancer risk due to gamma radioactivity in Kirklareli, Turkey. J Environ Radioact. 2009;100:49-53. DOI: $10.1016 /$ j.jenvrad.2008.10.012.

[15] Soil sampling for environmental contaminants. International Atomic Energy Agency, TECDOC-1415, Vienna, Austria; 2004.

[16] Quindos LS, Fernandez PL, Rodenas C, Gomez-Arozamena J, Arteche J. Conversion factors for external gamma dose derived from natural radionuclides in soils. J Environ Radioact. 2004;71:139-145. DOI: 10.1016/S0265-913X(03)00164-4.

[17] Amaral EM. Natural gamma radiation in air versus soil nature in Portugal. International Radiation Protection Association 10 - Hiroshima May 2000, Scientific Topics, Natural Radiation Exposure, Ref. P-1a-12.

[18] Sources effects and risks of ionizing radiation. Report to the General Assembly, With Annexes, United Nations Scientific Committee on the Effects of Atomic Radiation. New York, United Nations; 2008.

[19] Sources effects and risks of ionizing radiation. Report to the General Assembly, With Annexes, United Nations Scientific Committee on the Effects of Atomic Radiation. New York, United Nations; 2000.

[20] Harb S, El-Kamel AH, Abd El-Mageed AI, Abbady A, Rashed W. Concentration of ${ }^{238} \mathrm{U},{ }^{235} \mathrm{U},{ }^{226} \mathrm{Ra},{ }^{232} \mathrm{Th}$ and ${ }^{40} \mathrm{~K}$ for some granite samples in eastern desert of Egypt. Proc of the 3th Environ Physics Conf. 19-23 Feb. 2008, Aswan, Egypt: 109-117.

[21] Sources effects and risks of ionizing radiation. Report to the General Assembly, With Annexes, United Nations Scientific Committee on the Effects of Atomic Radiation. New York, United Nations; 1988.

[22] El-Daly TA, Hussein AS. Natural radioactivity levels in environmental samples in north western desert of Egypt. Proc of the 3th Environ Physics Conf. 19-23 Feb. 2008, Aswan, Egypt: 79-88.

[23] Sources effects and risks of ionizing radiation. Report to the General Assembly, With Annexes, United Nations Scientific Committee on the Effects of Atomic Radiation. New York, United Nations; 1993.

[24] Działalność prezesa Państwowej Agencji Atomistyki oraz ocena stanu bezpieczeństwa jądrowego i ochrony radiologicznej w Polsce w 2011 roku. Warszawa: Państwowa Agencja Atomistyki; 2012.

[25] Rozporządzenie Rady Ministrów z dnia 18 stycznia 2008 roku w sprawie dawek granicznych promieniowania jonizującego. DzU z dnia 3 lutego 2005 r., Nr 20, poz. 168. 


\title{
OCENA DAWKI PROMIENIOWANIA GAMMA NA ZWAŁOWISKACH
}

\author{
${ }^{1}$ Samodzielna Katedra Biotechnologii i Biologii Molekularnej, Uniwersytet Opolski
}

\begin{abstract}
Abstrakt: Eksploatacja złóż węgla kamiennego na terenie Górnego Śląska związana jest z produkcją bardzo dużych ilości odpadów składowanych na zwałowiskach. Badane próbki z terenów pięciu zwałowisk wykazywały różniącą się od siebie aktywność promieniotwórczą. Wykonane pomiary aktywności promieniotwórczej pozwoliły na dokonanie analizy stopnia zagrożenia za pomocą współczynników określonych przez UNSCEAR, takich jak ekwiwalent aktywności radu $R a_{e q}$, wewnętrzny $E_{\text {in }}$ i zewnętrzny $E_{e x}$ współczynnik obłożenia. Stwierdzono, że na obszarze zwałowisk występuje podwyższony poziom promieniowania w porównaniu do średniej rejestrowanej na obszarze kraju. Na badanym terenie nie występuje jednak zagrożenie związane z podwyższonym poziomem promieniowania w odniesieniu do norm ustanowionych przez Rozporządzenie Rady Ministrów w sprawie dawek granicznych promieniowania jonizującego.
\end{abstract}

Słowa kluczowe: zagrożenie radiologiczne, radionuklidy, dawka promieniowania 